Controversies 



\section{Grzegorz Krzywiec}

\section{Golden Harvest or Hearts of Gold? Studies on the Wartime Fate of Poles and Jews, edited by Marek J. Chodakiewicz, Wojciech J. Muszyński, Paweł Styrna (Washington DC: Leopolis Press, 2012); 370 pages.}

Just a few weeks after Golden Harvest by Jan Tomasz Gross and Irena Grudzińska-Gross appeared in bookstores, a collective response was published. Most of the authors are well known, with some of them actually being constant participants of the public debate in Poland throughout the last few years. Hence, they do not need an introduction.

The introduction to the Studies on the Wartime Fate of Poles and Jews (as the subtitle reads) states that the authors sought "truths about those times" and that the essays present "the results of their historical research and analyses" (p. 11). Then the editors did not omit to add that the collection "offers a corrective to the false and extreme portrayals of Polish-Jewish relations" (ibidem). So that there would be no doubt about their competence they add that "writers of these essays have been engaged in rigorous research, based on traditional logo-centric, and empirical constraints that scientific methodology requires, [...] [the authors will offer] the reader an exhaustive and multifaceted portrayal of relations between the Christian majority and Jewish minority [...]" (p. 12).

The comprehensive credo formulated by the two historians - Marek Jan Chodakiewicz and Wojciech Jerzy Muszyński - may be extracted already from the introduction. They write their truths of faith without quotation marks: "Because of Poland's isolation and the Polish scholars' complete absence from the Western scholarly exchanges and intellectual debates, the historical discourse concerning Polish-Jewish relations originated in the West in 1945, and has been dominated since, by Jewish voices, naturally driven to know and understand the greatest historical calamity that ever befell their people" (p. 13). According to Chodakiewicz and Muszyński, the Holocaust is today roughly a "means to reach people's minds and to portray ugly conservative, traditionalist and conservative attitudes" (p. 16).

What more do these new "representatives of Polish science in the Western scientific milieu" offer in addition to their active defense of the principles of "Truth, Good and Beauty"? Well, not much, for the reader learns little after penetrating the mush of newspaper clichés, somehow familiar slogans about "cultural Marxism" and pleas against postmodernism and totalitarian tyranny, which the modern world is supposedly slipping into. Panic and fear certainly 
seem to play key roles in their ideological self-definition. This idea frequently reappears in the introduction under various synonymous names. Fear of "stigmatization of defenders of tradition and freedom," of "the new quality in Poles', or actually post-Poles', self-comprehension," of homo novus as a new mutation of homo sovieticus and of "fetishization of minorities," and finally - as they loyally warn their potential readers - of the "danger of persecution, ostracism and stigmatization" (p. 17).

There are also some Manichean threads: "the discussion whose main topic is good and evil might determine what the World [sic] thinks about Poles and what Poles think about themselves." It needs to be openly said that some of the tasks, which those 'knights' of Western civilization set for themselves are highly ambitious: "[T] he authors of the present collection seek to restore the proper balance to the subject and the debate that surrounds it" (p. 15).

These 'nocturnal syntheses' continue in the essay "Reflections: A New Work, but the Same Old Method" by Prof. Marek Jan Chodakiewicz (Institute of World Politics). This author has the most theoretical ambition or, should I say, pretence. Hence, this discussion should begin with his essay. The editor of the study begins his text in an almost Hitchcock-like manner: "We have read Golden Harvest. It is a powerful blow in the vacuum. Our claim is based on our own general and also detailed, micrographic research" (p. 27). Chodakiewicz does not stint on this self-reference and auto didacticism until the very last paragraph. He briefly recalls his own bumpy path and a few of his own relevant aphorisms and winged words (e.g. "history is not a cut-out"). He had it hard not only abroad. ${ }^{1}$ Much suggests that besides the Institute of National Remembrance (Instytut Pamięci Narodowej, IPN) few thought him a pioneer of micro-history. But one might as well skip most of his reflections, which he has presented in 18 points for the reader's convenience. (For the record, it is difficult to regard the story about Paweł Zyzak Master of Arts, offered somehow as a dessert, as a separate whole). Chodakiewicz has often written on this topic in other publications. Besides,

${ }^{1}$ The following remembrance interpolation will be a delicacy for future biographers of this historian. "The present authors' monograph on the county of Kraśnik-Janów near Lublin is the only comprehensive case study to date in any language concerning the demography, economy, politics, underground, institutions, elites, majority population, minorities, and the occupiers between 1939 and 1947. [...] Our work had been deemed controversial even before we defended it. Nota bene, Gross was to be among the examiners, but resigned. Our supervisor, Prof. Istvan Deak resigned as well, as he simply did not want to fight for us. First, however, he wrote a letter 'no historian since Ranke's time has examined more primary sources' [...]. You are a true trailblazer" (43). The article is written in the first person plural (pluralis maiaestatis), which combined with the peculiarly venomous tone of the whole text produces an inadvertently farcical effect. For example, this is what Chodakiewicz writes about his visit to an archive. "The Archive of Modern Acts (AAN) in Warsaw contains, among many other Second World War documents, a report about the so-called Pinkert men (Pinkertowcy), the Jewish employees of the Pinkert funeral home in the Warsaw Ghetto" (p. 26). 
what is there to debate? Does anybody object that any historical research is based on evaluation of sources (reflection No. 1)? According to Chodakiewicz, post-modernism and de-construction are "a handy tool for literary fantasy [...] designed merely to challenge the foundations of western science" - reflection No. 2 "Banditry [...] scourged the Polish countryside" during the war - reflection No. 3 (p. 27). And this is how it continues to reflection No. 18, according to which modern liberalism is a straight path to nihilistic totalitarianism (p. 63). A more understanding reader could perhaps read those pretentious ideological confessions mixed with commonsense statements until the end; that is if he could tolerate so many truisms.

And this is a mere prelude. For most essays from this collection are "gems," and they all deserve some attention. Hence, there are more "maxims" or, as some would prefer to call them, absurdities. And they are to be found on each page. One might even conclude that the authors compete with one another in writing nonsense.

In Prof. Peter Stachura's essay or rather pamphlet, titled "Insults Instead of Facts: Notes on the Recent Debate on Poles and Jews" it is the insults that attract attention for they are much more numerous than facts.

One may then consider the arguments of Stachura. Characteristic features of Gross's previous publications beginning with his book on Jedwabne, wild generalisation based on the flimsiest or most partial and limited of evidence; distortion or wanton manipulation of material, and disregard of important fact, which would disprove or, at the very least, impugn his argument and interpretation; constitute his trademark. A marked degree of sophistry is another frequent trait. Moreover, these extremely dubious characteristics are expressed in a prose style [sic] that is not only invariably acerbic, but also prone to common sensationalism. In a word, Gross and traditional ideas of sound, empirically based and objective scholarship, intended to ascertain the true facts of historical circumstances, and to weigh them calmly in the interest of balance and clarity are irreconcilable. (p. 64) After such a robust dictum at the beginning of the text one might be curious to see how Stachura discredits Gross's expositions. But it is does not happen. Later on one may only read that in "many knowledgeable academic quarters, both in Poland and throughout the world Gross is reputed to be an anti-Polish propagandist with a craving for attention and publicity [...]" and of his "boundless impudence" and his "deep irrational animosity towards something or someone," [which] "invite[s] not only ridicule, but also unqualified contempt," about Gross's descriptions as "bordering on the perverse" and about the "facade" hiding a "disjointed and tendentious narrative." Gross's interpretations and appraisals are merely "a propaganda leaflet" that presents "selective, unrepresentative, and invariably trivial or localised incidents and data much of which is derived from the work of Jewish and minor, leftist Polish-based scholars" (p. 65) (here he mentions e.g. Saul Friedländer and Emanuel Ringelblum). Whew! 
When Stachura takes a deeper breath he concludes that Gross is a representative of a "typically Jewish obsession with ownership." Besides he allegedly "ignores completely, exaggerates, "manipulates [...] in order to accuse Poles groundlessly", contradicts his own theses and so on, and so on. Stachura would prefer to sentence "Gross's diatribes" to oblivion, but he is apparently hesitant even in this regard for after just a moment he warns that he will not let it all pass. He actually complains that it did not work out a few years back. "Perhaps it was caused by the lack of courage, if not cowardice, of contemporary Poland's political elites." Then he quickly and hopefully adds, that "in view of the new scandalous assault on Poles, political resolution should be formed in Warsaw, which would enable a significant official repudiation of Gross" (p. 70). An advocate of "direct action," he even gives the appropriate authorities hints as to what they might start with.

It should be said that the author must have exerted himself to list all those epithets, accusations and insults on just three pages. And what about the facts mentioned in the title? Here, Stachura was less generous. Surprisingly, on the two remaining pages he discusses the wartime situation in the Poznan area, which had little to do with the situation in the General Government or on most German-occupied Polish territory. Besides, the director of the Centre for Research in Polish History (Scottish University of Stirling) should know that in the former Prussian partition there were very few Jews (just a few per cent during the Second Republic of Poland period), who left little property (including movable property) and that the National Democratic Party (Narodowa Demokracja) effectively deprived that handful of Jews of access to the public sphere beginning from the early 1920s. One may only digress that Stachura considers one of Marek Jan Chodakiewicz's works "the most comprehensive and convincing [sic] refutation" of Jan Tomasz Gross's essays. By the way, the slogan is repeated by almost all of the authors.

The essay titled "If the Facts Are Against Us, Too Bad for the Facts': on Jan Tomasz Gross's Scholarly Method in Golden Harvest" by Doctor Piotr Gontarczyk, certainly does not lack a polemic character. The reader is likely to be surprised even at the beginning of the text for the author introduces himself as a Holocaust scholar (p. 72), which he did not boast of in the past. Moreover, he immediately declares that he will analyze everything using two criteria: the criterion of proper documentation and the criterion of critical analysis corresponding to the requirements of historical methodology.

And so already the photograph, which the Grosses use as a pretext for discussion, makes him conclude that it is a "truly interesting assessment of Gross's credibility" (p. 75). He complains that some fragments of Golden Harvest are "devoid of the most elementary credibility." And to prove that Gross's interpretations are "risky" and that his critique of the source is "rather amusing" he writes that Rachela Auerbach wrote a text about Treblinka diggers titled The Polish Colorado, which Gross suspected to have been titled Polish El Dorado (p. 76). 
Gontarczyk claims that Golden Harvest met with "a crushing critique," which seems a slight exaggeration for no historian denied the events describes in that publication.

To give an example of a statement not based on sources Gontarczyk quotes Gross's assertion that "one ought to presume that torture of Jews and the rape of Jewish women was a common occurrence at the time." The Golden Harvest author did present a few testimonies in the book to back up his statement and if one takes the trouble one can find many more testimonies in the works he refers to. Gontarczyk (born in 1970) replies: "My observations [my emphasis - G.K.] indicate the very opposite".

There are more such fireworks in the text. They are an example of the method he discusses at length and which he calls empiricism or positivism (which is a slight exaggeration). He usually picks a few, usually minor, incidents from the text (e.g. the issue of the $6^{\text {th }}$ Vilnius AK Brigade, p. 76 and the following ones) and makes them sound virtually absurd. He then adds the following sentence to a lengthy exposition full of rhetorical questions: "This generality constitutes a classic example of the fact that the book's narrative remains at odds with the quoted sources and has turned out to be a de facto confabulation by Jan Tomasz Gross" (p. 77). At the end he includes another sacramental formula: "examples can be multiplied," but he somehow always cautiously fails to present them.

Hence, the apostle of positivism verifies only a handful of Gross's distortions or examples of imprecision. Hence, the essay neither presents an alternative version of the incidents described in Gross's book nor offers their detailed revision or reinterpretation. It is merely a desperate attempt to find mistakes in it. It is visible in the interrogation-like attitude he adopts while looking for Gross's supposed intentions and motives. Here Gontarczyk really spreads his wings. Once and then again he plays his trump cards. He claims that Gross's motives are usually quite down-to-earth. He is not always one hundred per cent certain so he pretends to weigh his every word usually hiding behind neatly chiselled quotations. He wonders was Gross motivated by personal benefits or personal account settling? But the final sentence he passes on the Golden Harvest author is a crushing one: "in this world there are no rules" (99). As may be seen his telepathic skills do not go hand in hand with legendary technical skills. Apparently expression of opinions contradictory to his own not only proves lack of professional competence but also results in the opponent's total moral disqualification.

But Gontarczyk makes grave accusations not only against Gross. He spared neither the Warsaw ghetto chronicler Emanuel Ringelblum (the IPN upholder of the historical method's correctness begins the critique with the very title of his book $)^{2}$ nor most authors of the Holocaust. Studies and Materials yearly. Luckily, Gontarczyk mercifully spared the readers his reflections on Clifford Geertz's

${ }^{2}$ Gontarczyk concludes: “Yet, even the title of Ringelblum's book does not indicate that we are dealing with an in-depth scholarly study [...]" (p. 80). The comment concerns the follow- 
thick description technique. The initial versions of his essay published as articles in the Rzeczpospolita daily did contain such comments. ${ }^{3}$ Perhaps at the very last moment the author was told that demonstrating his ignorance is not necessarily a route to glory.

Piotr Gontarczyk's essay is an excellent example of the method used throughout the collection. Some of the authors begin with an initial, or one could perhaps say, original distortion, only to then conclude their quite vague expositions with a few banal theses. This is what e.g. Bethany M. Pałuk (a Ph.D. student, scholarly affiliation not stated) does in her essay titled "Looting as a Case Against Racial Determinism." Pałuk begins her thesis with the following statement. "Gross equates Polish Christians with the German Nazis" (p. 205). Later she particularizes, that "according to Gross, Jews and Christians are not guided by similar premises in their actions" (ibidem), and then that "[ $t$ ]his kind of thinking is the same type of logic that led the Nazis to advocate the extermination of whole peoples." (p. 201). To "expose the fallacy" of such thinking the author presents its "philosophical critique," and debates "the poverty of Gross's reductionist [sic] methodology" (p. 202), She also treats the reader to statements such as "there where he [that is, Jan Tomasz Gross - G.K.] sees only Christians looting Jewish property, a more objective observer might notice instances of Jews looting Christian property." But the author presents no such incident and does not refer to any parts of the Gross text.

The essay by Ryszard Tyndorf, a barrister from Canada, titled "Collective Rescue Efforts by Poles on Behalf of Jews in the German-occupied Polish Countryside" is devoid both of pasquilic accents and resentment. In the introduction the editors present him as "one of the leading world experts in the field of to documents regarding Polish-Jewish relations." The author, however, is known to the wider audience primarily for his publications in Nasz Dziennik. Tyndorf's essay enumerates a few hundred instances of help provided by Poles to the Jews hiding in the Polish countryside during the German occupation. Treated seriously, it would have perhaps been a good starting point of a polemic with at least a few theses from the Grosses' latest book. But the essay features no analysis, no initial attempt to critically juxtapose such instances and not even, which is all the more surprising, an ordinary critique of the source, which the other authors of the collection often call for. Works of a critical-historical character are mixed with testimonies and memoirs, which makes the whole article chaotic. But the positive aspect of it is that the author tries to discuss the issue, which Golden Harvest is about instead of talking about himself. It is difficult to qualify the second part ("Methodology") for it includes texts of various kinds. [...] Father Prof. Waldemar Chrostowski's essay titled "Moral Dilemmas in Turbulent Times" would be

ing publication: Polish-Jewish Relations during the Second World War, ed. Joseph Kermish, and Shmuel Krakowski (Evanston: Northwestern University Press: 1992).

${ }^{3}$ Cf. Rzeczpospolita, http://www.rp.pl/artykul/623119.html, retrieved 12 October 2011. 
a casual and a highly general moral reflection if it were not for the veiled ideological interpolations about the present. Father Chrostowski's pious reflections furtively go from the darkness of World War II (of course in Father Professor's opinion the Catholic Church described it the most comprehensively through its hierarchs and teaching) toward the times when "various thinkers and researchers, safe and sound in their studies" articulate "aggressive" judgments and, making matters worse, are "increasingly impudent." Father Chrostowski makes a farfetched but clear allusion to the situation in the Middle East and to the current financial crisis, or rather to its victims, with whom he sympathizes. What does it have to do with Golden Harvest? Does Jan Tomasz Gross have something to do with the swindles of great international finance? ${ }^{4}$ Chrostowski's parable is not entirely clear might be interpreted in various ways. Some would notice traces of the Catholic social teaching, but that dating back to the turn of the $19^{\text {th }}$ and $20^{\text {th }}$ century, i.e. the era of Karl Lueger and Father Stanisław Stojałowski. Yet others, e.g. readers of Nasz Dziennik, where Father Chrostowski often publishes his texts, shall perhaps merely notice dreary and sinister consequences of the "weaken[ing of] the bonds of [...] national solidarity." It is suggested; for the author gives a few indirect hints that on the one hand it is about peculiarly defined hypocrisy and "lining one's own pockets" on the other. Consequently, all those who "force [...] an examination of conscience" should be loyally warned. Their efforts are pointless.

Essays by Judge Barbara Gorczycka-Muszyńska ("Whose Tenements? A Legal Analysis of the Status of Former Jewish Property in Light of Post-war Polish Law") and Doctor Tania C. Mastrapa ("Prawo własności prywatnej a godność jednostki: przykład Kuby" [Private Property Rights and Individual's Dignity: Cuban Example] $)^{5}$ are basically about the same topic, i.e. the issue of the lot of the appropriated private property. It seems that it is not a coincidence that Gorczycka-Muszyńska has the same surname as another author and editor of the collection. Doctor Tania C. Mastrapa is the founder and chairperson of Mastrapa Consultants - a company, which according to her short biography, restitutes property on Cuba. Gorczycka-Muszyńska's exposition is an erudite and intricate legal argument. It ends with a quite simple conclusion that "this favor conferred upon the Jewish minority was a product of extra-legal factors" (p. 230). The judge does spare the reader her reflections on the communists of Jewish descent ("żydokomuna") aside from a cleverly chosen part of a testimony of a "Jew from Lublin." Obviously nothing tastes as good as a quotation

\footnotetext{
${ }^{4}$ This is how Father Prof. Chrostowski weaves the thread of his parable. "Let us consider a contemporary analogy. The recent financial crisis saw billions of dollars evaporate. But money does not simply evaporate. It only changes hands. One may legitimately ask whether the contemporary mass theft is stigmatized and condemned with the same zeal and vociferousness as the above deeds." (p. 229).

${ }^{5}$ The text was not included in the English translation (translator's footnote).
} 
of a real Jew in a parable with an anti-Semitic tag line! Those interested might be intrigued by the information Gorczycka-Muszyńska found in American Jewish Year Book and in contemporary scientific studies and which, as her exposition suggests, casts another flash of truth on the background of the Kielce pogrom. The author writes: "The scope of this phenomenon [Jewish property restitution - G.K.] may be gauged by the example of the city of Kielce where hundreds of buildings and other real estate unit were returned to their former Jewish owners by mid-1946" (p. 230).

Tania C. Mastrapa reflects on a more exotic situation, i.e. that in Cuba after the Cuban Revolution. Some might say that the two cultural contexts - those of occupied Poland and communist Cuba - seem different. But Mastrapa sees various clear analogies and disregards the difficulties she encounters. Not all associations appealed to my imagination, but it is my chronicler's duty to note that Doctor Mastrapa has made perhaps the greatest effort possible to present the issue of looted property to the world. ${ }^{6}$

The essays by John Radziłowski and Wojciech Jerzy Muszyński from the collection win the nonsense writing competition by several lengths. The former's essay titled "The Neo-Stalinist Discourse in Polish Historical Studies in the United States" was perhaps an attempt to characterize "a school of Polish historical study," which, as one may conclude from his exposition, is a group of historians dealing with recent Polish history. What is "neo-Stalinism" and the "neoStalinist turn," to leave the trendy word discourse on the margin? (Incidentally, Radziłowski misapplies that word). It is not at all easy to discern its constitutive characteristics in the tangle of the accusations. Furthermore, Radziłowski actually makes it clear that "[t]his is not to suggest that present-day neo-Stalinist historians are devotees of the Soviet dictator Joseph Stalin or even that they are doctrinaire Marxists in the strict sense of the term" (sic) (p. 244). A moment later the author floods his readers with a stream of accusations against "cultural Marxism," postmodernism, "the blurring of the differences between any

${ }^{6}$ A characteristic comparison from the text. "The situation in Cuba is in a way similar to the situation of humiliated wives in the past. It often happened that the husband, who constrained his wife, did not let her study, work outside home or drive a car. Her role was to work, obviously for free, for the sake of the family. She was not allowed to participate in making budget decisions or any other decisions for the money belonged to the husband. Such a woman lived devoid of respect and dignity. In turn the husband wanted her to be content and happy for in his opinion he provided her with everything she needed. When the woman finally began to break free from this humiliating situation and did not allow any more subjugation the authoritarian husband, who fears losing control over his property, began to complain and criticize and attack her. Similarly to that endangered husband who wants to criticize his wife and does not want to give her personal freedom, the Castro regime does not want its property (i.e. the Cubans) to be free [...]. When the Cubans recover their freedom they will become lawful owners of real estate and moveable property" (p. 257 in the Polish edition). 
form of patriotism or service to one's country" only to then freely pass on to the criticism of the "existing paradigm of Polish villainy," counter-culture, hostility toward Christianity and other (at times contradictory) atrocities. The only certain thing is the fact that Radziłowski cordially hates all these afflictions together and each of them separately. Much suggests that the function of "neoStalinism" in that exposition is analogous to the role that the epithet "Jew" performs for an anti-Semite and the epithet "communist" for an anti-communist. Everything connects with everything here as long as it is sufficiently disgusting and harmful. According to Radziłowski, it is not so much the chimerical nature of "neo-Stalinism" which is so intriguing in the text as the depth of the roots he thinks "new-Stalinism" has taken. The study scrupulously states that "neoStalinism" has certainly been dominant in the American social sciences since the 1960s. If one reads Radziłowski's wordy essay literally then one may conclude that apart from him and a few authors (including the authors of the collection) most American historians are still engaged in that enterprise. Furthermore, this Soviet-European-American implant seems to have been a danger to Polish social life since the 1990s. Finally, after a lengthy exposition, the author states that "neo-Stalinism may also be seen as a historiographic offensive bringing turmoil to Polish intellectual, cultural and social life in years following 1989" (p. 246). Leaving the author with his phantasmagoria, one needs to note that it seems that this vague exposition is based on the conviction that Radziłowski and other "independent researchers" possess an inaccessible truth and that he would wish to enlighten a wider audience. Perhaps this is where he found the perverse idea to include his elucubration in this collection.

But Doctor Wojciech Jerzy Muszyński's article is a masterpiece in itself. For those not in the know I should stress that for over a decade Muszyński has been one of the most prolific researchers of the "Polish nationalist movement." He has nearly an entire shelf of publications devoted to that topic (by the way most of them published by the IPN). Muszyński is the author that embarks on perhaps the boldest task. He strives to prove that the biggest anti-Semitic mass movement on Polish territory in the $20^{\text {th }}$ century manifested its phobia of Jews at the level of political slogans, which had almost no impact on everyday life. Similarly to most of the authors he calls for sine ira et studio research, but he also promises a serious reflection on the "rational motivations of the Polish nationalists' antiJewish program in the first half of the twentieth century." (p. 294). From the very beginning he strives to prove that the National Democratic Party had nothing to do with Nazism. One needs to admit that he was quite successful but with one fundamental reservation. His whole line of reasoning may be reduced to a thesis that the National Democratic Party was not an exact copy of the Nazi party. And here the "full-time" expert on "nationalist" movements slightly simplified his task. It would be a truly international phenomenon if a nationalist movement were an exact copy of another one from not only another country but also from an enemy country. 
His further expositions give the reader an even harder time. The author tries to prove e.g. that the nationalist periodicals did not cross the line of affirmation of violence and here, referring to the line of reasoning he has proposed earlier, he takes a shortcut. For who had systematically organized anti-Semitic street riots, demonstrations and pogroms in Poland every year since the beginning of the 1930s until the outbreak of World War II (or even since the late 1920s when the Youth Movement of the Camp of Great Poland [Ruch Młodych Obozu Wielkiej Polski] was created)? Surely the author does not discuss all that because of lack of space. Instead Muszyński writes about Polish nationalism of the 1930s as an "oasis of serenity," which in this context sounds more than ridiculous. Perhaps the author should refresh his memory and browse through the testimonies of young "nationalist" organizers of boycotts at universities and street riots, which he systematically publishes as the Glaukopis editor-in-chief. But one needs to agree with Muszyński on one thing. This subject matter - anti-Semitic violence organized by various fractions of the National Democratic Party and its successors - should be approached in a more systematic and comprehensive manner. The number of over 50 casualties of the pogrom terror usually given by the historians is but a tip of an enormous iceberg of everyday, less spectacular and usually unregistered violence, of assaults and minor physical attacks, of destruction of property and possessions and of constant blackmail and harassment. All that awaits its researchers.

Wojciech Jerzy Muszyński never misses an opportunity to repeat that there was no racism or eugenic movement in the "Polish nationalist movement." But it is perhaps neither half nor even one-quarter true. For how would he categorize the leading racists of that period such as Ignacy Oksza-Grabowski, Stanisław Pieńkowski or Zygmunt Wasilewski - major National-Democratic journalists, each of whom was for some time the editor-in-chief of Myśl Narodowa (which Muszyński regards as a periodical representing a moderate attitude toward Jewish issues)? How would he qualify Jędrzej Giertych's Rasizm ograniczony (a manifesto text published in the National Party (Stronnictwo Narodowe) semi-official organ Gazeta Warszawska at the end of 1934) ${ }^{7}$ or Rasizm duchowy (Stanisław Piasecki's ideological manifesto published in the intelligentsia periodical Prosto

\footnotetext{
${ }^{7}$ Giertych wrote: "We do not think it impossible for even a pure-blood Jew to become a true and complete Pole. Just as we do not deem it impossible for even a pure blood Jew to become a Catholic saint. But we think that such cases are few and far between. It is not easy for the spirit to gain a total victory over the body, even when it consciously tries to fight that body [...]. Hence, in practice something close to racism is a justified attitude. Even though we admit that there are exceptions [my emphasis - G.K.], we claim that in average cases, in that sum of facts which constitutes the general picture, the race determines whether somebody has something to do with Jewry or not. And this is why in advance we do not trust a person who is a pureblood Jew or has some Jewish blood in him. Only when we become convinced that this very person deserves to be deemed an exception are we ready to be rid of this distrust" ("Rasizm ograniczony," Gazeta Warszawska, No. 377, 16 December 1934).
} 
z Mostu)? Similarly to Reinhard Heydrich, Piasecki - if one is to stay with those analogies - despite his "uncouth" origins, but what about the others? What about a lengthy essay about "Aryan" Europe by Roman Dmowski (the senior of the "nationalist movement") published in the "Duch Europy" (Spirit of Europe) series in Polityka Narodowa at the beginning of 1938? One should not forget here the nationalist fathers of the Polish "racial" policy: Jan Czekanowski, Karol Stojanowski and Ludwik Jaxa-Bykowski. It would not be easy for Muszyński, even considering what a zealous archive researcher he is, to find so many prominent anthropologists among the luminaries of any other European fascist party.

Perhaps the author of the essay titled "The Polish Nationalists: A Mainly Theoretical Anti-Jewishness" should examine more closely the texts from the era he writes about. Here is one of many examples. While reading Jędrzej Giertych's brochure titled Kajakiem po Niemczech. Listy z podróży (Pelpin, 1936) - one of the most infamous apologies of the Third Reich's solution to the Jewish question - Muszyński came to the conclusion that Giertych would not have become a Nazi even if he had been a German. But the essayist raises the bar for the leading National Party activist much too high, for he demands that he refer to ancient Germanic mythology and beliefs. Such heroism was not required even of the NSDAP members. Unless Muszyński tries to prove that the early German beliefs were a criterion of Nazism but then both Adolf Hitler and Joseph Goebbels and Julius Streicher would have surely had no access to that formula. To prove that it was true would be a discovery as significant as John Radziłowski's introduction of the concept of "neo-Stalinism" into the "scientific legacy of the West." And one might multiply examples of such minor manipulations and sometimes of ordinary negligence, for they appear on each page until the end of the book. And there one needs to brace oneself for statements such as this: "Thus, according to the nationalists, the only possible and beneficial way for Poland to diffuse this Polish-Jewish conflict of interests would be a complete or almost complete removal of this minority from Polish soil" (p. 314). According to Muszyński, this was a "rational" conclusion of the National-Democratic program from the period after World War II.

It is difficult not to acquire the impression that the author of this lengthy essay puts his readers to the test quite a few times. This calculation must result in a conviction that the reader shall swallow any nonsense. This text, which defies not only common sense but also ordinary decency, is in the third part of the book ("Comparative History"). All these texts (especially those by Chodakiewicz, Father Chrostowski and Radziłowski) suggest that the modern world is an arena of a constant, apocalyptic and total war for lasting, even an eternal memorial, in which the Jews imposed their version of history.

Having read these "positivist" essays one is left with a more tangible reaction: the hunger for facts. One might well believe that almost all of the "logocentrics" dose their findings as carefully as a pharmacist. Gontarczyk has established beyond all doubt that Rachela Auerbach wrote about Colorado and not El Dorado. 


\section{6}

Paweł Styrna (author of a "monumental study about the Wólka Okrąglik and Gniewczyna hamlets", whose excerpts are to be found in the essay titled "The Tale of Two Hamlets: The Cases of Wólka Okrąglik and Gniewczyna") established that Tadeusz Markiel - author of a moving testimony about the massacre in Gniewczyna - was a PRL "jarhead" (trep) and thus anything he says totally disqualifies him. ${ }^{8}$ Sebastian Bojemski (author of the text titled "The Polish Nationalists and the Jews: Everyday Practice During the German Occupation; and the Case of the National Armed Forces (NSZ)," which is somehow a sequel of Muszyński's essay) found a few testimonies proving that numerous Jews joined the NSZ, which welcomed them with open arms. And finally Tania C. Mastrapa, the guest from Cuba, informs the readers in whose house General Wojciech Jaruzelski is living. The last sensational finding is, as it seems, a result of a fruitful international cooperation with her colleagues from the IPN investigation division. And as far as new facts are concerned, not to mention interpretations, this would be it.

A few authors declare that there is a need to or even a purpose in researching the issues that Jan Tomasz Gross and Irena Grudzińska-Gross discuss in their book. Nothing suggests, however, that they undertook that effort themselves. Their texts are not so much polemics as rather interventional political commentaries. It should be immediately added that they are disposable products. The Golden Harvest or the Hearts of Gold? collection of essays is actually neither a content-related dispute with the Grosses' book's theses ${ }^{9}$ nor even an aggressive philippic against them. Hence, it is certainly not a collection of questions, reflections and research doubts addressed to the two authors on the occasion of their latest publication. For the main problem with Golden Harvest has remained largely untouched. What is significant in the Grosses' essays has been largely ignored and its sense has been distorted. The collection does not discuss any problematic or controversial issues, which would disturb the Olympian composure of the Searchers of truth with a capital letter "S" and "logocentrics" from across the Atlantic. Consequently, this supposedly comprehensive analysis of Golden Harvest balances on the thin line between sheer manipulation (texts

8 "Nor are we told of any other potential functions Markiel may have discharged within the structures of the Communist state's military-security complex. [...] Are Markiel's stories about his former neighbors, admittedly grim and horrific albeit unverified by any research guided by any personal motives? On the ideological plane [...] his testimony resembles a propaganda lecture generated by the Communist Main Political Board of the Polish People's Army." (p. 153).

${ }^{9}$ Marek Jan Chodakiewicz admits that himself. In order to retain his unique style and tone of writing, it seems beneficial to quote this excerpt in extenso: "A scientific and empirical debate about Golden Harvest is pointless. It is as pointless as to consult leading surgeons after a rural quack doctor has hacked the patient to pieces and ordered the other quack doctors to use the same type of 'treatment' in similar cases. Why, there are more quack doctors in the world than leading surgeons. The former will win every democratic race with the latter" (p. 64). The passage is printed on the jacket of the book. 
by Bojemski, Gontarczyk and Muszyński), a primitive incriminating letter (Stachura) and parish priest-like allegory with a pseudo-theological lecture (Father Prof. Chrostowski's text) and refers to hackneyed platitudes about the nation's innocence, its heroism and national pride in the hostile world. Jewish collaboration is the only taboo in the Polish-Jewish relations the authors of these studies notice, and actually here almost all of them would be ready, or even race one another, to beat not their own breasts.

But it is neither just another publication from the extensive library of antiGross pamphlets nor, plainly speaking, a "Gross-reversed" book, even though at least some of the authors of the collection would like it to be. So what links those essays apart from the unanimous conviction that Marek Jan Chodakiewicz, the leading "logocentric" from across the Atlantic, has spoken the final word regarding the Polish-Jewish relations and the Holocaust?

Most of these studies, apart from few mentioned exceptions, offer a quite faithful record of the neurotic state of mind of many Polish historians and of what constitutes their background - persistent obsessions, ritually repeated fetishes and ideological phrases they use and in which they see nothing wrong. It occurs that some paranoid visions are worthy of periodicals such as Nasza Polska, Opcja na Prawo, Gazeta Polska or recently especially Najwyższy Czas (in the collection there is even an essay by that periodical's editor-in-chief, Tomasz Sommer, who this time poses as an authority on visual sociology), which sometimes force their way into mass circulation dailies or even prevail in some, mixed with elements of the historical technique, are marketable and sometimes surprisingly far-reaching. This collection circulates the book market as a reply to Golden Harvest.

Of course, one could go deeper into some confessions of the authors. But why? There is something farcical about the conception of a crusade against the modern world professed by a few researchers from a marginal research centre, ${ }^{10}$ which is a recruitment pool of the CIA. ${ }^{11}$ But could this McCarthyism drenched in the East European "sauce" with the whole peculiar, local color; this "information

${ }^{10}$ Supported by an interesting coalition - a "voluntary mobilisation of people of goodwill." To omit it here would be a pity. "Among them are descendants of Polish nobility, of the $19^{\text {th }}$ century insurgents, legionaries, and soldiers of other formations from the First World War, of the persons deported to Siberia, of the prisoners of gulags, of the prisoners of Auschwitz and other Nazi camps, as well as of the children of the Zamość region, of the forced laborers in the Third Reich, of the Righteous among the Nations [...] as well as of the soldiers, airmen, and sailors of the Polish Armed Forces in the West and the pro-independence underground from the period of World War II and the post-war times." Plus "the Michelangelo of radio astronomy," a clinical psychologist, "committed girls from the Ivy League," well-wishers from Facebook, acquainted researchers from a few IPN centers, and, of course, almost the entire editorial staff of Glaukopis, including the proofreaders" (pp. 22-23).

${ }^{11}$ The Institute of World Politics, www.iwp.edu/about/page/welcome-to-iwp, retrieved 10 July 2011. 
depositary," as Chodakiewicz and Muszyński state in the introduction, worthy of 1930s right-wing political leaflets and then slightly filtered through the 2011 Poland political correctness, survive anywhere else abroad?

This collection is more like the material for a seminar of linguists or even scholars of rhetoric and propaganda. The book will not be good nourishment for readers interested in the Holocaust and its third phase, i.e. the basic topics of the essays by Jan Tomasz Gross and Irena Grudzińska-Gross. So what else is left if one disregards the fact that Marek Jan Chodakiewicz and his colleagues have by the sheer keenness of their minds penetrated the laws of history and modern development, that they have read and diagnosed the fears of the contemporary world and even revealed another face of the veiled totalitarianism freely raging by the River Vistula, and if one were to spare oneself Gontarczyk's technical fireworks? It does not change the fact that one will surely become involved with most of those authors and surely quite often. They are engaged in a persistent dialogue with a numerous group of people who see the world in a similar way and they do not care at all about anybody else.

P.S. The collection features an article by Teresa Prekerowa, who died in 1998 (published earlier in Biuletyn Głównej Komisji Badania Zbrodni przeciwko Narodowi Polskiemu [1993], vol. 35). She was an extraordinary figure from the occupation period and at the same time an eminent specialist on World War II Polish-Jewish relations.

Everything suggests that the text became a fig leaf for a certain simple truth. But it is not a truth written in a lofty manner or with a capital letter. How did it come to pass that this reliable text, minimalist in its concept but highly transparent in its conclusion ended up in this hybrid of a volume? 